\title{
Experiment Research on Manufactured Fine Aggregate about one Precast Beam with C55 Concrete on Guiyang-Chongqing Railway
}

\author{
Ling ZHOU \\ Scientific Research and Design Institute of CSCEC \\ Guiyang, P. R. China \\ E-mail: 170610979@qq.com
}

\begin{abstract}
Through benchmark concrete proportion to material composed of adaptability and efficiency test, add special preparation of concrete admixture, mechanism of different stone powder content of sand sand mechanism of C55 high performance concrete performance impact study. The test results show that the special additive for different stone powder content adaptability is stronger, the mechanism of sand preparation by 28 days compressive $\mathrm{C55}$ concrete compressive strength of $70 \mathrm{Mpa}$, the air content is $3 \%$, satisfies the requirement of pumping.
\end{abstract} railway

Keywords-C55; manufactured fine aggregate; concrete;

\section{INTRODUCTION}

With the acceleration of national infrastructure construction, the demand for concrete is growing, corresponding, the requirement for sand also increased sharply. In many karst region, such as yunnan, guizhou and other places, there are poor of sand resources, this will give the local infrastructure construction brought a great deal of inconvenience.

Such as chongqing section of the river sand used in construction of double line railway guizhou qian mainly comes from the dongting lake in hunan, its use cost is higher, and stop for the phenomenon. Guizhou is a general mechanism of sand resources, local distribution as it is reasonable use, can become the main sand source of railway construction.

Although the national related standards allowed in the case of river sand is not easy to achieve mechanism sand concrete can be used, but for all levels of concrete mechanism sand made strict limits, especially in the area of stone powder content limit strictly. According to the production technology level of the common, most without air separation or water processing mechanism of sand stone powder content between 10 to $15 \%$, far higher than the standard limit of stone powder content is $7 \%$. Therefore, can be used on engineering mechanism sand made of high strength concrete has a lot of controversy, mainly reflected in using mechanism sand preparation of high strength concrete workability can meet the needs of the pumping and stone powder content is bad influence on the durability of concrete structure, etc.

The aim of this experiment is by optimizing the ratio of concrete and admixture compound with research, formulate the pump, air content, strength parameters, such as up to the standards of railway construction specification of C55 concrete with artificial sand are required.

\section{TeSt MATERIALS AND MethoD}

\section{A. Materials}

Cement used guizhou P.O 52.5 cement of lafarge cement factory production, its various performance indexes meet the common Portland cement GB175-2007, specific parameters are shown in table 1.

Manufactured sand used local qian peng sand production mechanism, the stone powder content is $12 \%$, fineness modulus of 2.9, and the specific parameters are shown in table 2 .

Concrete admixture mother liquor selects the 'shangrao tianjia' new materials co.LTD, the production of poly (carboxylic acid is, through repeatedly, the additive sodium dodecyl sulfate, 422 \#, basf, air-entraining agent composition such as distribution.

\section{B. Method}

The test method of this study is mainly based on the concrete construction quality acceptance standard railway TB 10424-2010, the railway concrete construction technology guide, etc. Test items include: slump, extension, rewinding time, air content, compressive strength and the electric flux.

\section{Test RESUlts}

\section{A. Study on Benchmark Mix Pruportion of Concrete}

Group in accordance with the relevant railway concrete standard to try to match C55 pumping mechanism sand concrete (try match strength requirement 3 d reached $90 \%$, air content of 3-5\%), and to select the benchmark ratio, based on the admixture of formula is optimized, the mechanism of sand concrete structure durability performance for the next step research laid the foundation, the test results of the desired purpose. C60 mechanism sand concrete mixture ratio design and the test results are shown in table 3 (uniform dosage of admixture of gelled material is $1.0 \%$ ).

As can be seen from table 3 , from the early strength and workability, group 2 mixture satisfies the requirement of related parameters, and is more economic. Therefore this research will be 2 groups as a benchmark mixture into the next phase of research. 


\section{B. Study on Admixture}

After repeatedly try to benchmark mixture ratio match, team found C55 mechanism sand air content of concrete in each group the variation coefficient is larger, the air content from $2 \%$ to $6 \%$ all have checked out, this is beyond the standard requirements and the quality control of concrete. Through the analysis, may be a air-entraining admixture composition of mechanism sand caused more sensitive to changes of stone powder content. So the research of concrete admixture formula was studied.

Group of the admixture of gas composition was used for screening, selection of sodium dodecyl sulfate, 422\# basf trial with air-entraining agent and air-entraining composition, and the results as shown in figure 1 and 2 .

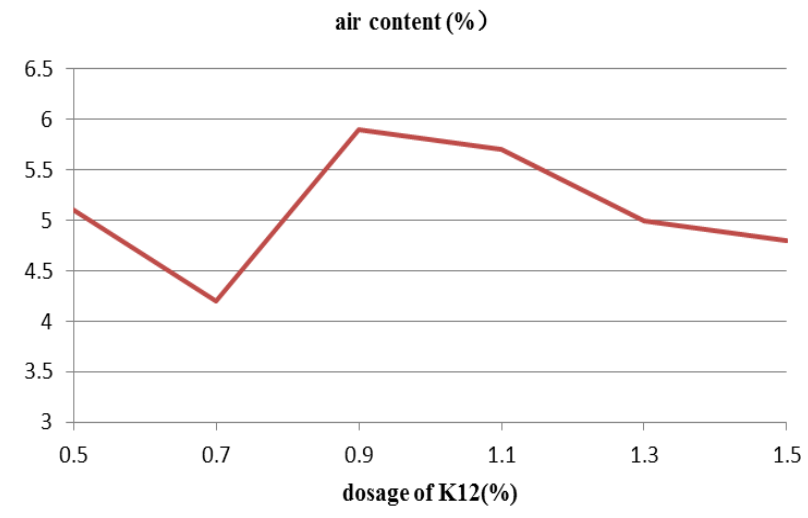

Figure 1. Relationship between air content and dosage of K12.

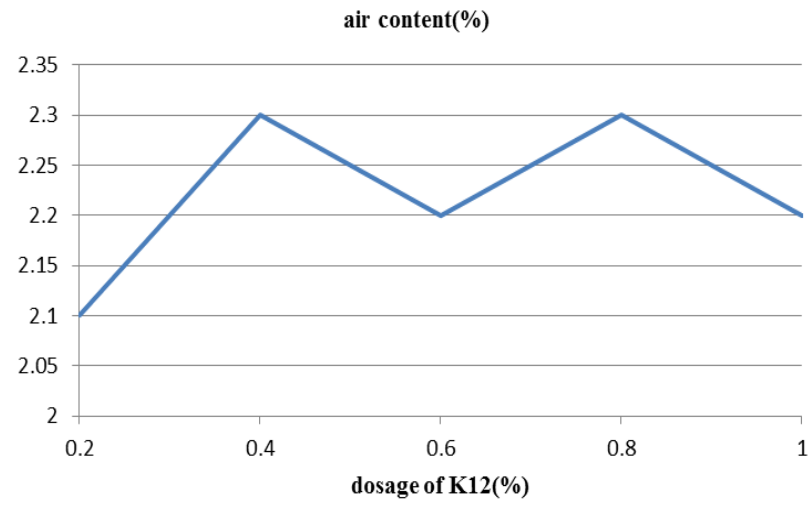

Figure 2. Relationship between air content and dosage of $422 \#$.

It's can be seen from figure 1, a separate mixed with sodium dodecyl sulfate, air content and its content is no obvious relationship and air content on the high side (with a value between 4 6\%); And separate mixed with 422 \# basf, air-entraining agent, air content and stable at a lower level (including the volume value between $2 \sim 2.5 \%$ ). Separately using two kinds of air-entraining agent effect is not ideal (air content standards between $3 \sim 5 \%$ ).

Therefore, the research will be sodium dodecyl sulfate and 422 \# basf air-entraining agent double mixing (mass ratio of 3:2) join admixtures, found that the air content and double mixing admixture is a linear relationship between stability and air content value between $3 \sim 5 \%$, meet the standard requirements, successfully solved the new mixing mechanism sand air content of concrete is not stable. The results is shown in figure 2 .

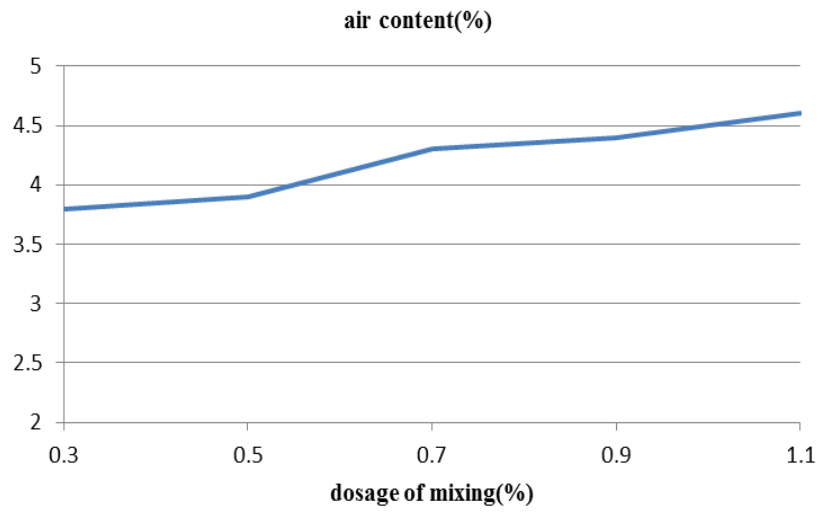

Figure 3. Relationship between air content and dosage of mixing.

\section{Influence of Stone Powder Content on the Concrete}

The group through the screening was carried out on the mechanism of sand, stone powder content in the artificial mechanism of sand increase or decrease, and the mechanism of sand control of stone powder content is $7 \%, 9 \%, 11 \%$, $13 \%$ and $15 \%$ five gears, basic covers local common stone powder content. Choose before the benchmark of C55 concrete mixture ratio and double mixing admixtures, test of C60 concrete related performance (the results are shown in table 4), the test results show that the double mixing admixtures good adaptability for the mechanism of different stone powder content in the sand, the preparation of C55 concrete can meet the pumping performance, compressive strength, air content and other technical requirements, to achieve the desired purpose.

\section{Durability Research}

In accordance with the specifications for design of railway concrete durability (TB 10005-2010), combined with engineering to the environment types and grades, group key to electric flux to evaluate the mechanism of different stone powder content sand of C55 concrete durability, the test results meet the construction requirements.

\section{CONCLUSION}

Mechanism of sand stone powder content on the high side of high grade concrete workability, pumping and durability index is not easy to meet the requirements of relevant regulations and standards. This research through scientific and rational design of mix proportion and the admixture of compound with research methods, such as the mechanism of stone powder content in $7 \%$ to $15 \%$ of the sand used in the preparation of C60 pumping concrete, after the examination, technical indicators meet the chongqing railway qian a precast beam using standard specification requirements. 


\section{ACKNOWLEDGMENT}

This work is financially supported by the fund science and technology cooperation of Guizhou province [2015] 3013/cscec-4b-2014-kt-06.

\section{REFERENCES}

[1] Tian Jianping. The preparation and study on properties of high strength and high performance MSC [D]. Wuhan:Wuhan University of Technology, 2006.(in chinese)

[2] Sun Yongtao. Application research of manufactured sand and concrete [D]. Chengdu:Southwest Jiaotong University, 2007.(in chinese)

[3] Wang Jiliang. Research of effects and mechanism of manufactured sand characteristics on portland cement concrete [D]. Wuhan:Wuhan University of Technology, 2008.(in chinese)

[4] Wang Guangming. Discussion new building materials manufactured sand [J]. Sichuan Architecture, 2011,31(6): 202-204. (in chinese)
[5] Rafat Siddique. Performance characteristics of High-Volume class Fly Ash Concrete [J]. Cement and Concrete Research, 2004,34: 4547.

[6] Yang Chao. Manufactured sand pump concrete mix design of the C50 T-beam [J]. Technoloy wind, 2011, (5):118,113. (in chinese)

[7] Jiang Zhengwu, Pan Feng, Wu Jianlin.et al. Effects of manufactured sand parameters to concrete performance [J]. China Concrete, 2011, (26):66-67. (in chinese)

[8] Yue Haijun, Li Beixing, Zhou Mingkai.et al. Study and experiment of manufactured sand size grading for purperse of cenment concrete [J]. Concrete, 2012, (3):91-94. (in chinese)

[9] Ai changfa, Peng Hao, Hu Chao.et al. influence law and action effect of manufactured sand gradation on concrete performance [J]. Concrete, 2013, (1):73-76. (in chinese)

[10] Zhang Huizhi, Liu Jifeng. Experimental study of full machine-made sand concrete match ratio used in south to north water diversion project [J]. Journal of Henan University of Science and Technology: Natural Science, 2013, 34(1):64-68. (in chinese)

TABLE I. TABLE PERFoRMANCE METRICS OF CEMENT

\begin{tabular}{|c|c|c|c|c|c|c|c|c|c|c|}
\hline \multirow[t]{2}{*}{ label } & \multirow[t]{2}{*}{ stability } & \multirow[t]{2}{*}{ condensed water/ $\%$} & & \multicolumn{2}{|c|}{$\begin{array}{l}\text { setting time } \\
\text { / h:min }\end{array}$} & \multicolumn{2}{|c|}{$\begin{array}{c}\text { compressive strength } \\
/ \mathrm{MPa}\end{array}$} & & \multicolumn{2}{|c|}{$\begin{array}{l}\text { flexural strength } \\
\text { / MPa }\end{array}$} \\
\hline & & & & $\frac{\text { initial }}{2: 45}$ & $\frac{\text { final }}{7: 30}$ & $\frac{3 d}{28.3}$ & \multicolumn{2}{|l|}{$\frac{28 \mathrm{~d}}{57.5}$} & $3 \mathrm{~d}$ & $28 \mathrm{~d}$ \\
\hline \multicolumn{11}{|c|}{ TABLE II. TABLE PERFORMANCE METRICS OF CEMENT } \\
\hline Single quality $\mathrm{m}_{\mathrm{i}}(\mathrm{g})$ & 38.8 & 129.5 & 96.3 & 52.3 & 58.7 & 33.8 & & 30.6 & & 60.0 \\
\hline Triage $\mathrm{a}_{\mathrm{i}}(\%)$ & 7.76 & 25.90 & 19.26 & 10.46 & 11.74 & 6.76 & & 6.12 & & 12.00 \\
\hline
\end{tabular}

TABLE III.

TABLE C55 CONCRETE MiXTURE RATIO

\begin{tabular}{ccccccc}
\hline & & \multicolumn{3}{c}{ ratio/kg } \\
\cline { 2 - 6 } & cement & sand & rock & F-ash & powder \\
\hline 1 & 360 & 765 & 1015 & 45 & 60 & water \\
2 & 380 & 725 & 1055 & 55 & 50 & 154 \\
3 & 400 & 700 & 1065 & 65 & 45 & 156 \\
\hline
\end{tabular}

TABLE IV. TABLE THE RESUlts

\begin{tabular}{|c|c|c|c|c|c|c|c|}
\hline $\begin{array}{c}\text { stone } \\
\text { powder } / \%\end{array}$ & $\begin{array}{l}\text { slump } \\
/ \mathrm{mm}\end{array}$ & $\begin{array}{l}\text { slump- } \\
\text { flow } \\
\text { /mm } \\
\end{array}$ & $\begin{array}{c}\text { inverted } \\
\text { time } \\
/ \mathrm{s}\end{array}$ & $\begin{array}{c}\text { air content } \\
1 \%\end{array}$ & $\begin{array}{c}3 \mathrm{~d} \\
\text { compressive } \\
\text { strength/MPa }\end{array}$ & $\begin{array}{c}7 \mathrm{~d} \\
\text { compressive } \\
\text { strength/MPa }\end{array}$ & $\begin{array}{c}28 \mathrm{~d} \\
\text { compressive } \\
\text { strength/MPa }\end{array}$ \\
\hline 7 & 210 & 600 & 7 & 3.4 & 55.0 & 60.2 & 71.1 \\
\hline 11 & 210 & 600 & 8 & 3.3 & 56.2 & 61.5 & 70.4 \\
\hline 13 & 220 & 580 & 7 & 3.5 & 55.8 & 61.2 & 73.2 \\
\hline
\end{tabular}

